\title{
Long term surgical outcomes for infective endocarditis in people who inject drugs: a systematic review and meta-analysis
}

\author{
David Goodman-Meza ${ }^{1,2^{*}} \mathbb{D}$, Robert E. Weiss ${ }^{3}$, Sebastián Gamboa ${ }^{4}$, Abel Gallegos ${ }^{4}$, Alex A. T. Buil, \\ Matthew B. Goetz ${ }^{1,2}$, Steven Shoptaw ${ }^{6}$ and Raphael J. Landovitz ${ }^{1,7}$
}

\begin{abstract}
Background: In recent years, the number of infective endocarditis (IE) cases associated with injection drug use has increased. Clinical guidelines suggest deferring surgery for IE in people who inject drugs (PWID) due to a concern for worse outcomes in comparison to non-injectors (non-PWID). We performed a systematic review and meta-analysis of long-term outcomes in PWID who underwent cardiac surgery and compared these outcomes to non-PWID.

Methods: We systematically searched for studies reported between 1965 and 2018. We used an algorithm to estimate individual patient data (elPD) from Kaplan-Meier (KM) curves and combined it with published individual patient data (IPD) to analyze long-term outcomes after cardiac surgery for IE in PWID. Our primary outcome was survival. Secondary outcomes were reoperation and mortality at 30-days, one-, five-, and 10-years. Random effects Cox regression was used for estimating survival.

Results: We included 27 studies in the systematic review and 19 provided data (KM or IPD) for the meta-analysis. PWID were younger and more likely to have S. aureus than non-PWID. Survival at 30-days, one-, five-, and 10-years was 94.3, 81.0, 62.1, and 56.6\% in PWID, respectively; and 96.4, 85.0, 70.3, and 63.4\% in non-PWID. PWID had $47 \%$ greater hazard of death (HR 1.47, 95\% Cl, 1.05-2.05) and more than twice the hazard of reoperation (HR 2.37, 95\% Cl, 1.25-4.50) than non-PWID.

Conclusion: PWID had shorter survival that non-PWID. Implementing evidence-based interventions and testing new modalities are urgently needed to improve outcomes in PWID after cardiac surgery.
\end{abstract}

Keywords: People who inject drugs, Endocarditis, Surgery, Meta-analysis

\section{Background}

The estimated prevalence of people who inject drugs (PWID) increased worldwide from 2008 to 2017 [1, 2]. PWID are exposed to a wide variety of infectious diseases via injection practices. These infections include HIV, hepatitis B and C viruses, and bacterial and fungal infections. In the United States, the prevalence of people reporting injection drug use in the past year is low (0.3\%) [3], yet PWID accounted for 9\% of all new HIV cases in 2015 [4] and there has been a more than

\footnotetext{
* Correspondence: dgoodman@mednet.ucla.edu

'Division of Infectious Diseases, David Geffen School of Medicine at UCLA, 10833 Le Conte Ave (Room 37-121CHS), Los Angeles, CA 90095-1688, USA ${ }^{2}$ Infectious Diseases, VA Greater Los Angeles Healthcare System, Los Angeles, CA, USA

Full list of author information is available at the end of the article
}

twofold increase in new HCV cases from 2004 to 2014 [5]. In PWID, however, other bacterial and fungal infectious complications including infective endocarditis (IE) are often overlooked [6].

IE is a severe bacterial or fungal infection of the heart valves, often with blood-stream contamination, with high morbidity and mortality. In PWID, mortality from IE varies from 25 to 35\% [7, 8]. IE has increased in PWID, likely related to the recent overall increase in PWID. In the US, the increase in IE has been disproportionate in those who are white, younger, female, and living in rural communities $[9,10]$. In comparison to people who do not inject drugs (non-PWID), PWID with IE are typically younger, and have fewer comorbidities or predisposing heart conditions; but are more likely to have more recurrences of IE,

(c) The Author(s). 2019 Open Access This article is distributed under the terms of the Creative Commons Attribution 4.0 International License (http://creativecommons.org/licenses/by/4.0/), which permits unrestricted use, distribution, and 
be living with HIV, have right-sided valvular disease, and have Staphylococcus aureus as the etiologic agent [9-12]. The cost of treating the recurrences of IE of one person who injects drugs was estimated to be $\$ 380,000$ over a 2year period [13]; the total costs for treating IE in PWID $(n=46)$ at one hospital was over $\$ 8$ million in 2012 [14]. Between 2007 to 2017, the costs in North Carolina were estimated to be $\$ 78$ million [15]. In the US, the total costs for treating bacterial infections in PWID was over $\$ 700$ million in 2012 [16].

In complicated cases of IE, surgery may be necessary. However, for PWID, surgeons may defer indicated surgery out of concern for worse outcomes largely attributable to reinfection. Indications for surgery in IE classically include signs of severe heart failure, uncontrolled infection (virulent or resistant organisms, persistently positive blood cultures, or perivalvular complications), prevention of embolic events (large vegetations, prior episodes of embolic events), among others [17-19]. Despite a demonstrated mortality benefit for valve replacement surgery in specific clinical scenarios of IE [20-22], US IE guidelines recommend avoiding surgery in PWID if possible due to concerns for reinfection events from continued injecting practices [19]. The ethics of limiting cardiac surgery in PWID has been debated in the literature, and interventions such as signed-contracts agreeing to abstinence, multidisciplinary-team treatment approaches, and even a "three-strike rule" have been proposed [23-30].

Recently, Hall et al. reported a systematic review and meta-analysis that compared survival outcomes at 30 days and in-hospital mortality between PWID and nonPWID [31]. This study found no difference in mortality between the groups early after cardiac surgery. In the present study, our aim was to estimate the long-term survival in PWID post-cardiac surgery for IE, comparing these outcomes to non-PWID. We performed a systematic review and meta-analysis of studies that reported survival after cardiac surgery for patients with IE with the objective to inform clinical practice and future interventions designed to improve outcomes in PWID who are provided surgery for IE.

\section{Methods}

The protocol and methods were registered on PROSPERO, number CRD42018093727 [32]. We report our findings following PRISMA-IPD guidelines [33].

\section{Literature search}

We systematically searched PubMed, Embase, Scopus, and Google Scholar using terms: "injection drug use" or "people who inject drugs" and "infective endocarditis" and "surgery." The search strategy for each database is provided in Additional file 1: Table S1. We limited our search to human studies between 1965 and 2018. To reduce publication bias, we included both published manuscripts and unpublished conference abstracts. All searches were done between April and May of 2018. We searched the databases without language restriction but only included articles published in English or Spanish. We reviewed the reference list of included articles for other articles that fit our inclusion criteria.

\section{Selection criteria}

We included studies that fulfilled the following criteria: 1) retrospective or prospective design; 2) individuals with infective endocarditis; 3 ) underwent a surgical cardiac procedure (for example, replaced or repaired a heart valve); and 4) reported baseline or outcomes data for PWID separately from non-PWID. For studies that reported inclusion of PWID but reported their baseline or outcomes data in combination with non-PWID, we contacted the corresponding author for the possibility of separating the data by PWID and non-PWID. We excluded articles that reported data for fewer than 5 PWID.

\section{Data extraction and quality assessment}

Two authors (SG and AG) searched PubMed, Embase, Scopus, and Google Scholar electronic databases for studies that met the inclusion criteria and extracted data independently and in duplicate. We created a standardized protocol for reviewing studies and entered relevant information in an electronic database. Any disagreement in study inclusion or data entry was resolved by consensus of the two authors (SG and AG), or inclusion of a third reviewer (DGM). We extracted data tables for demographic, microbiologic, and valve disease characteristics. For our outcomes, we extracted Kaplan-Meier curves of survival for mortality and reoperation, or tables that reported outcomes for each individual participant. We assessed the quality and reporting of each study using the Newcastle-Ottawa Scale for observational studies. This scale has eight items in three categories: selection, comparability, and outcome. It systematically rates items with one star in the selection and outcomes categories, and up to two stars in the comparability category.

\section{Variables}

We collected data from each study that included location, period of study, age, and gender. We categorized microbiologic pathogens as Staphylococcus aureus, coagulase negative staphylococci (CONS), Streptococci ssp., Enterococci (we counted Group D Streptococci from older studies with Enterococci), gram negative rods (GNR) or others, Candida, or culture negative. We 
extracted data regarding valve-related disease that included the location of the diseased valve (aortic, mitral, tricuspid, pulmonary) and created a separate variable to denote if multiple valves were affected. We also extracted data related to embolic events and prosthetic valve IE. The primary outcome was overall survival defined as the time from cardiac surgery for IE until death, and the secondary outcome was time-to-reoperation survival. We provide estimates for 30-day, 1-year, 5-year, and 10-year survival.

\section{Statistical analysis}

For summary statistics of gender, microbiologic, and valve related characteristics, we summed across studies and calculated percentages. We compared PWID and non-PWID with random-effects meta-analysis. For summary of age, we used random-effects meta-analysis of the mean. To study long-term outcomes, we used a published algorithm by Guyot et al. [34] to estimate individual patient data (eIPD) from digitized Kaplan-Meier curves or used published individual patient data (IPD). The Guyot method was validated by the algorithm's authors [34] and in a subsequent simulation study [35]. When counts of subjects at risk at regular intervals were absent in the original article, we assumed constant censoring as recommended in the original methodology publication [34]. With the eIPD and IPD, we performed a one-step random effects meta-analysis. In the one-step approach, we pooled all the eIPD and IPD and used a mixed effects Cox Proportional Hazards model to estimate survival in PWID and compare with non-PWID. We adjusted for study and PWID-status by study interaction as random effects of the baseline hazard. We plotted Kaplan-Meier curves broken out by study and constructed a forest plot for the comparative studies. We assessed publication bias visually by funnel plots. All analyses were performed in $\mathrm{R}$ ( $\mathrm{R}$ Development Core Team, Vienna, Austria) using packages survminer [36], survival [37], and meta [38].

\section{Results}

We identified 21,857 records in the literature search and excluded 4797 duplicates (Fig. 1). Of the remaining 17, 060 , we excluded 16,805 by reviewing the title, abstract

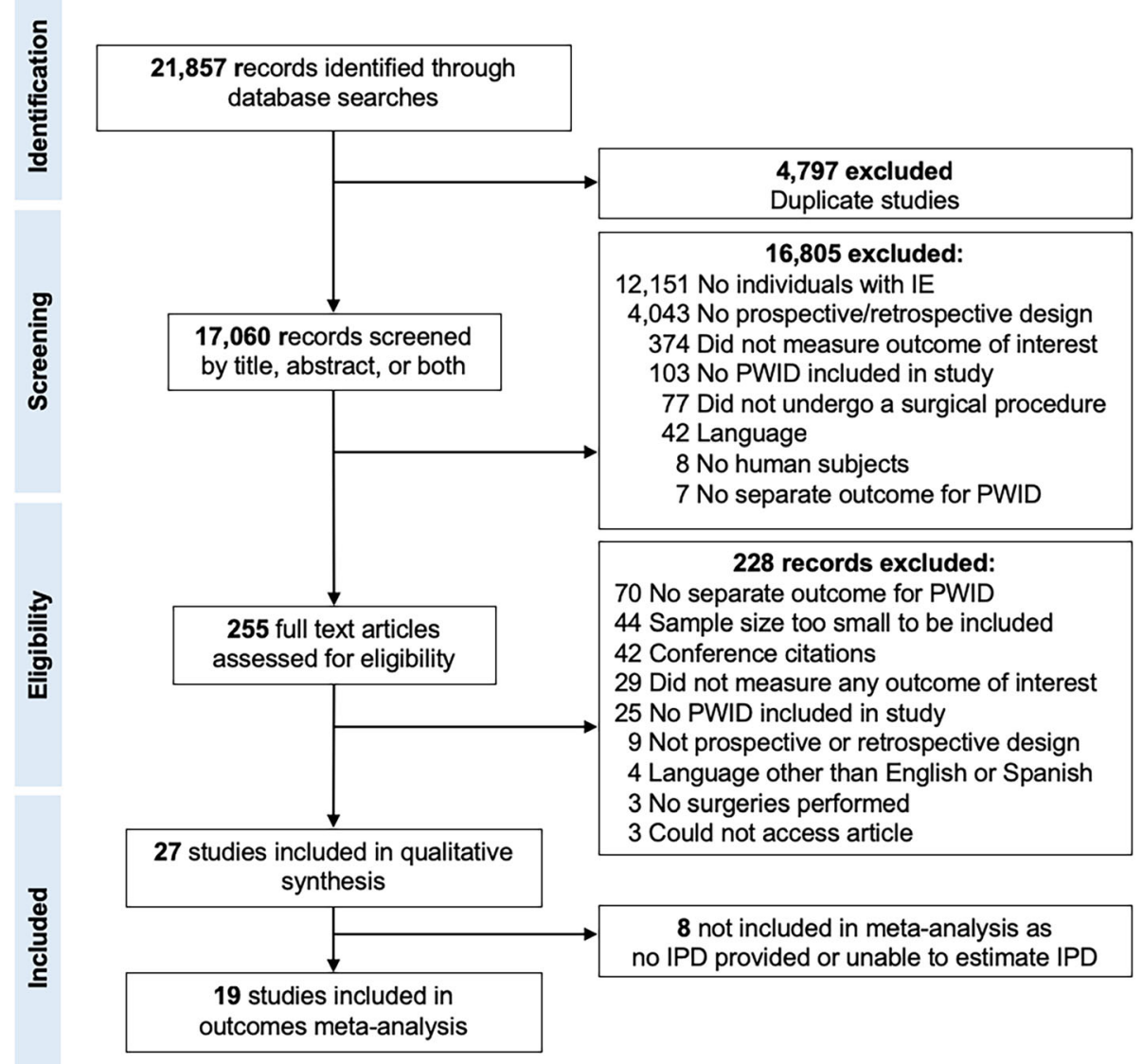

Fig. 1 Flow diagram of the study selection process. Abbreviations: IE Infective endocarditis, IPD Individual participant data, PWID People who inject drugs 
or both. Of 255 remaining records, 228 were excluded by reviewing the body text. We included 27 studies in our qualitative assessment, (Additional file 1: Table S2). All studies were retrospective: 11 compared PWID vs non-PWID, and 16 only reported data for PWID. The majority of studies were from the US (15), followed by Germany (3), Canada (2), Spain (2), Sweden (2), England (1), Italy (1), and Switzerland (1). We recreated eIPD from 13 studies that published Kaplan-Meier curves using the Guyot algorithm and created Kaplan-Meier curves from five studies that published an IPD table (Carrell, Frater, Hubbell, Mammana, and Shetty) and used these data for our primary outcome analysis. Three studies provided survival curves for time-to-reoperation and were used for our secondary outcome analysis. Maximum follow-up ranged from 52 days to 29 years. Data was reported for 926 PWID and 1822 non-PWID. Patients in both PWID and non-PWID groups were majority male, 68.2 and $69.1 \%$, respectively. PWID were younger than non-PWID (mean age, 34.9 years, 95\% CI 32.4-37.7, vs. 51.4 years, 95\% CI 46.9-56.3, $p<0.001$ ). Table 1 describes the characteristics for the included studies.

\section{Microbiology}

In total, 2141 microbiologic pathogens were reported, 738 in PWID from 24 cohorts, and 1403 in non-PWID from nine cohorts. Staphylococcus aureus $(43.0 \%$ vs. $24.7 \%, p=0.001$ ) was more common in PWID than in non-PWID. Streptococci $(29.4 \%$ vs. $16.7 \%, \mathrm{p}<0.001)$, coagulase-negative Staphylococci $(13.4 \%$ vs. $3.7 \%, p<$ $0.01)$, Enterococci $(12.1 \%$ vs. $7.3 \%, \mathrm{p}<0.01)$, and culture negative endocarditis $(9.6 \%$ vs. $5.8 \%, p=0.01)$ were more common in non-PWID than in PWID. Summarized microbiologic data are presented in Table 2, and by study microbiologic data are available in Additional file 1: Table S3.

\section{Valve data}

The number and type of affected valves were reported by all studies. Two papers (Thalme and Asgerisson) combined valve-related data of those in whom surgery was and was not performed and were not included in aggregated totals. Embolic events were reported for PWID in 10 studies, and non-PWID in six studies. Valve data are presented in Table 2. A total of 2874 valves were included: 922 in PWID and 1952 in non-PWID. In PWID, $39.7 \%$ of surgical procedures involved the aortic valve, $33.5 \%$ the tricuspid valve, and $25.6 \%$ the mitral valve. In non-PWID, $53.1 \%$ of surgical procedures involved the aortic valve, $36.8 \%$ the mitral valve, and $9.6 \%$ the tricuspid valve. Prosthetic valve endocarditis was more common in non-PWID than PWID (30.2 vs. $7.9 \%, p<0.01$ ).
Valve data is broken out by study in Additional file 1: Table S4.

\section{Outcomes in PWID and non-PWID}

In one-step random effects meta-analysis of mortality with eIPD from 13 studies and IPD for 5 studies, we included data for 649 PWID and 1578 non-PWID. In PWID, survival was $94.3,81.0,62.1$ and $56.6 \%$ at 30 -days, one-, five-, and ten-years, respectively. In non-PWID, survival was $96.4,85.0,70.3$, and $63.4 \%$ at 30-days, one-, five-, and tenyears, respectively (Additional file 1: Table S5). In the mixed effects Cox Proportional Hazards model, the hazard ratio (HR) for PWID was 1.47 (95\% CI 1.05-2.05, $p=0.02$ ) compared to non-PWID thus non-PWID survive significantly longer than PWID after valvular surgery for IE. Pooled survival curves are presented in Fig. 2. Survival curves by study are presented in Additional file 1: Fig. S1. Survival curves for reoperation were reported by three studies. We estimated IPD for 183 PWID and 986 non-PWID. PWID had a higher hazard of reoperation than non-PWID (HR 2.37, 95\% CI, 1.25-4.50, $p<0.01$ ). In PWID, median survival to reoperation was 78.1 months (Fig. 3). Funnel plots to visually assess for publication bias were reported in Additional file 1: Fig. S2 and Fig. S3, for the mortality and reoperation outcomes, respectively.

\section{Discussion}

The number of cases of IE in PWID has increased in the US linked to the ongoing opioid epidemic $[6,67]$. Consequently, the number of IE cases linked to PWID that require cardiac surgery has also risen, and ethical dilemmas in the decision to offer surgery to PWID have resulted. In this meta-analysis using eIPD and IPD we demonstrated a shorter long-term survival after cardiac surgery for IE for PWID compared to non-PWID. PWID had significantly worse outcomes than non-PWID at 5- and 10-years postcardiac surgery. At 5 years, PWID had close to $40 \%$ mortality. It is notable that on average, PWID who underwent cardiac surgery for IE were approximately 16 years younger than those that are non-PWID. Evidence-based interventions are urgently needed to improve survival in PWID who undergo valve surgery for IE.

There are likely many reasons for the observed mortality and survival disparities. PWID were more commonly infected with $S$. aureus, a highly virulent pathogen associated with worse outcomes in all patients with IE [68]. A higher proportion of PWID infected with $S$. aureus likely led to decreased survival in this group. In parallel to the increase in PWID in the US, invasive methicillin resistant $S$. aureus (MRSA) infections have more than doubled in PWID from 2011 to 2016 and PWID are 16 times more likely to have an invasive MRSA infection than non-PWID [69]. Moreover, MRSA infections have 
Table 1 Characteristics of included studies

\begin{tabular}{|c|c|c|c|c|c|c|c|c|c|}
\hline Author & $\begin{array}{l}\text { Year } \\
\text { Published }\end{array}$ & Location & Period & PWID & $\mathrm{n}$ & $\begin{array}{l}\text { Age, } \\
\text { mean } \pm S D\end{array}$ & $\begin{array}{l}\text { Male, } \mathrm{n} \\
(\%)\end{array}$ & $\begin{array}{l}\text { Maximum follow- } \\
\text { up (years) }\end{array}$ & Notes \\
\hline Arbulu [39] & 2000 & Detroit, USA & $\begin{array}{l}1970- \\
1990\end{array}$ & Yes & 55 & $N A \pm N A$ & $\bullet$ & 29 & Kaplan Meier reported for 36 patients. \\
\hline \multirow[t]{2}{*}{$\begin{array}{l}\text { Asgeirsson } \\
{[40]}\end{array}$} & 2016 & $\begin{array}{l}\text { Karolinska, } \\
\text { Sweden }\end{array}$ & $\begin{array}{l}2004- \\
2013\end{array}$ & Yes & 10 & $\begin{array}{l}38.7 \pm \\
12.75\end{array}$ & $77(64)$ & 1 & \multirow[t]{2}{*}{$\begin{array}{l}\text { Data reported for surgical and } \\
\text { non-surgical cases together. }\end{array}$} \\
\hline & & & & No & 27 & $65.6 \pm 8.25$ & $96(77)$ & 1 & \\
\hline \multirow[t]{2}{*}{ Baraki [41] } & 2013 & $\begin{array}{l}\text { Hannover, } \\
\text { Germany }\end{array}$ & $\begin{array}{l}1996- \\
2012\end{array}$ & Yes & 9 & & $\bullet$ & & \multirow{2}{*}{$\begin{array}{l}\text { Demographic data reported together. } \\
\text { IPD reported in table but survival for } \\
\text { survivors not reported. }\end{array}$} \\
\hline & & & & No & 45 & $42 \pm 16.2$ & $\begin{array}{l}37 \\
(68.5)\end{array}$ & 5 & \\
\hline \multirow[t]{2}{*}{ Boyd [42] } & 1977 & $\begin{array}{l}\text { New York, } \\
\text { USA }\end{array}$ & $\begin{array}{l}1970- \\
1975\end{array}$ & Yes & 14 & $N A \pm N A$ & $\bullet$ & 15 & \multirow{4}{*}{$\begin{array}{l}\text { Demographic data reported together. } \\
\text { Kaplan Meier not separated by PWID } \\
\text { and non-PWID. }\end{array}$} \\
\hline & & & & No & 19 & $49 \pm 21$ & $\begin{array}{l}19 \\
(57.6)\end{array}$ & 15 & \\
\hline \multirow[t]{2}{*}{ Carozza [43] } & 2004 & Naples, Italy & $\begin{array}{l}1980- \\
2004\end{array}$ & Yes & 39 & $32.1 \pm 8.1$ & $\begin{array}{l}35 \\
(89.7)\end{array}$ & 10.5 & \\
\hline & & & & No & 85 & $33.4 \pm 8.2$ & $\begin{array}{l}57 \\
(67.1)\end{array}$ & 10.5 & \\
\hline Carrell [44] & 1993 & $\begin{array}{l}\text { Zurich, } \\
\text { Switzerland }\end{array}$ & $\begin{array}{l}1989- \\
1991\end{array}$ & Yes & 10 & $23.4 \pm 3.2$ & $7(70)$ & 20 & Reconstructed IPD from published table. \\
\hline Dawood [45] & 2015 & $\begin{array}{l}\text { Baltimore, } \\
\text { USA }\end{array}$ & $\begin{array}{l}2002- \\
2012\end{array}$ & Yes & 56 & $39 \pm 12$ & $\begin{array}{l}23 \\
(41.1)\end{array}$ & 11 & Included 6 patients who were non-PWID \\
\hline \multirow[t]{3}{*}{ Frater $[46,47]$} & 1989 & Bronx, USA & $\begin{array}{l}1984- \\
1987\end{array}$ & Yes & 9 & $N A \pm N A$ & $\bullet$ & 2.75 & Reconstructed IPD from published table. \\
\hline & & & $\begin{array}{l}1977- \\
1980\end{array}$ & Yes & 10 & $N A \pm N A$ & $\bullet$ & 9 & No Kaplan Meier or patient table. \\
\hline & 1990 & Bronx, USA & $\begin{array}{l}1977- \\
1989\end{array}$ & Yes & 57 & $N A \pm N A$ & $\bullet$ & 10 & Combined previous cohorts \\
\hline Hubbell [48] & 1981 & $\begin{array}{l}\text { San Francisco, } \\
\text { USA }\end{array}$ & $\begin{array}{l}1965- \\
1976\end{array}$ & Yes & 27 & $33 \pm 12.1$ & $57(72)$ & 11 & $\begin{array}{l}\text { Demographic data reported together } \\
\text { for surgical and non-surgical. } \\
\text { Reconstructed IPD from published table. }\end{array}$ \\
\hline \multirow[t]{2}{*}{ Kaiser [49] } & 2007 & St. Louis, USA & $\begin{array}{l}1986- \\
2005\end{array}$ & Yes & 62 & $39 \pm 9$ & $\begin{array}{l}37 \\
(59.7)\end{array}$ & 19.1 & $\begin{array}{l}\text { Microbiologic data only for } 31 \text { of } 62 \text { in } \\
\text { PWID. }\end{array}$ \\
\hline & & & & No & 284 & $54 \pm 15$ & $\begin{array}{l}185 \\
(65.1)\end{array}$ & 18.8 & \\
\hline \multirow[t]{2}{*}{ Kim [50] } & 2016 & Boston, USA & $\begin{array}{l}2002- \\
2014\end{array}$ & Yes & 78 & $35.9 \pm 9.9$ & $\begin{array}{l}48 \\
(61.5)\end{array}$ & 10 & \\
\hline & & & & No & 358 & $59.3 \pm 14.1$ & $\begin{array}{l}247 \\
(69)\end{array}$ & 10 & \\
\hline Levitsky [51] & 1982 & Chicago, USA & $\begin{array}{l}1976- \\
1981\end{array}$ & Yes & 37 & $34.6 \pm N A$ & $\begin{array}{l}31 \\
(83.8)\end{array}$ & 5 & No SD reported. Age range $20-52$ \\
\hline $\begin{array}{l}\text { Mammana } \\
\text { [52] }\end{array}$ & 1983 & Chicago, USA & $\begin{array}{l}1976- \\
1979\end{array}$ & Yes & 18 & $33.7 \pm 10.3$ & $\bullet$ & 3 & Reconstructed IPD from published table. \\
\hline $\begin{array}{l}\text { Martin-Davila } \\
{[53]}\end{array}$ & 2005 & Madrid, Spain & $\begin{array}{l}1985- \\
1999\end{array}$ & Yes & 26 & $33 \pm N A$ & $\bullet$ & 12 & $\begin{array}{l}\text { Non-PWID were excluded because they } \\
\text { were not separated by surgical and } \\
\text { non-surgical patients. }\end{array}$ \\
\hline Marks [54] & 2015 & $\begin{array}{l}\text { London, } \\
\text { England }\end{array}$ & $\begin{array}{l}1998- \\
2010\end{array}$ & Yes & 11 & $27.8 \pm 4.8$ & $\bullet$ & 52 days & $\begin{array}{l}\text { Data reported together for surgical and } \\
\text { non-surgical }\end{array}$ \\
\hline Mathew [55] & 1995 & Chicago, USA & $\begin{array}{l}1982- \\
1991\end{array}$ & Yes & 80 & $37.7 \pm 10$ & $\begin{array}{l}58 \\
(72.5)\end{array}$ & 7.5 & \\
\hline Mestres [56] & 2003 & $\begin{array}{l}\text { Barcelona, } \\
\text { Spain }\end{array}$ & $\begin{array}{l}1985- \\
2002\end{array}$ & Yes & 21 & $28.2 \pm 6.5$ & $\begin{array}{l}18 \\
(85.7)\end{array}$ & 10.8 & \\
\hline $\begin{array}{l}\text { Nelson }[57, \\
58]\end{array}$ & 1984 & $\begin{array}{l}\text { Los Angeles, } \\
\text { USA }\end{array}$ & $\begin{array}{l}1972- \\
1982\end{array}$ & Yes & 27 & $32.9 \pm N A$ & $\begin{array}{l}37 \\
(7110)\end{array}$ & 10 & $\begin{array}{l}\text { Demographic data reported together } \\
\text { for PWID and non-PWID. Group D }\end{array}$ \\
\hline
\end{tabular}


Table 1 Characteristics of included studies (Continued)

\begin{tabular}{|c|c|c|c|c|c|c|c|c|c|}
\hline Author & $\begin{array}{l}\text { Year } \\
\text { Published }\end{array}$ & Location & Period & PWID & $n$ & $\begin{array}{l}\text { Age, } \\
\text { mean } \pm S D\end{array}$ & $\begin{array}{l}\text { Male, } n \\
(\%)\end{array}$ & $\begin{array}{l}\text { Maximum follow- } \\
\text { up (years) }\end{array}$ & Notes \\
\hline & & & & No & 25 & $38 \pm N A$ & & 10 & $\begin{array}{l}\text { streptococcus counted as enterococcus. } \\
\text { No SD reported. Age range 9-58 }\end{array}$ \\
\hline Osterdal [59] & 2016 & $\begin{array}{l}\text { Bergen, } \\
\text { Norway }\end{array}$ & $\begin{array}{l}2001- \\
2013\end{array}$ & Yes & 29 & $39.7 \pm 11.2$ & $\begin{array}{l}27 \\
(93.1)\end{array}$ & 9.4 & \\
\hline \multirow[t]{2}{*}{$\begin{array}{l}\text { Pfannmueller } \\
{[60]}\end{array}$} & 2015 & $\begin{array}{l}\text { Leipzing, } \\
\text { Germany }\end{array}$ & $\begin{array}{l}1995- \\
2012\end{array}$ & Yes & 11 & $33.5 \pm 4.29$ & $8(72.7)$ & 15 & \\
\hline & & & & No & 45 & $60.1 \pm N A$ & $\begin{array}{l}31 \\
(68.9)\end{array}$ & 15 & $\begin{array}{l}\text { Used meta-analysis of mean of two } \\
\text { non-PWID groups to obtain mean age }\end{array}$ \\
\hline \multirow[t]{2}{*}{ Rabkin [61] } & 2012 & Seattle, USA & $\begin{array}{l}1999- \\
2010\end{array}$ & Yes & 64 & $43.5 \pm 10.9$ & $\begin{array}{l}45 \\
(70.3)\end{array}$ & 6.6 & $\begin{array}{l}\text { Grouped S. aureus and CONS. For } \\
\text { analysis, considered as S. aureus. }\end{array}$ \\
\hline & & & & No & 133 & $48.4 \pm 17.9$ & $\begin{array}{l}97 \\
(72.9)\end{array}$ & 10.3 & \\
\hline Shetty [62] & 2016 & $\begin{array}{l}\text { Nova Scotia, } \\
\text { Canada }\end{array}$ & $\begin{array}{l}2008- \\
2011\end{array}$ & Yes & 7 & $33.4 \pm 12.1$ & $4(57.1)$ & 2 & Reconstructed IPD from published table. \\
\hline \multirow[t]{2}{*}{ Shrestha [63] } & 2015 & $\begin{array}{l}\text { Cleveland, } \\
\text { USA }\end{array}$ & $\begin{array}{l}2007- \\
2012\end{array}$ & Yes & 41 & $38 \pm 11$ & $\begin{array}{l}26 \\
(63.4)\end{array}$ & 6 & \\
\hline & & & & No & 495 & $59 \pm 14$ & $\begin{array}{l}342 \\
(69.1)\end{array}$ & 6.4 & \\
\hline $\begin{array}{l}\text { Silverman } \\
\text { [64] }\end{array}$ & 1984 & Chicago, USA & $\begin{array}{l}1976- \\
1983\end{array}$ & Yes & 14 & $N A \pm N A$ & $\begin{array}{l}11 \\
(78.6)\end{array}$ & 7 & \\
\hline \multirow[t]{2}{*}{ Thalme [10] } & 2009 & $\begin{array}{l}\text { Stockholm, } \\
\text { Sweden }\end{array}$ & $\begin{array}{l}1994- \\
2000\end{array}$ & Yes & 60 & $39 \pm 5.9$ & $\begin{array}{l}31 \\
(51.7)\end{array}$ & 3.3 & $\begin{array}{l}\text { Combines both surgical and non-surgical. } \\
\text { Reason for differences in n ( } 5 \text { PWID and } \\
27 \text { non-PWID) }\end{array}$ \\
\hline & & & & No & 135 & $64 \pm 19.2$ & $\begin{array}{l}75 \\
(55.6)\end{array}$ & 9.4 & \\
\hline $\begin{array}{l}\text { Weymann } \\
{[65]}\end{array}$ & 2014 & $\begin{array}{l}\text { Heidelberg, } \\
\text { Germany }\end{array}$ & $\begin{array}{l}1993- \\
2013\end{array}$ & Yes & 20 & $35 \pm 7.7$ & $13(65)$ & 16.6 & \\
\hline \multirow[t]{2}{*}{ Ying [66] } & 2013 & $\begin{array}{l}\text { Ottawa, } \\
\text { Canada }\end{array}$ & $\begin{array}{l}2003- \\
2012\end{array}$ & Yes & 24 & $39.4 \pm 2.1$ & $\begin{array}{l}17 \\
(70.8)\end{array}$ & 10 & Reported as abstract, never published. \\
\hline & & & & No & 171 & $59.1 \pm 1$ & $\begin{array}{l}127 \\
(74.3)\end{array}$ & 10 & \\
\hline
\end{tabular}

Abbreviations: CI Confidence interval, PWID People who inject drugs, non-PWID people who do not inject drugs, SD standard deviation

worse outcomes compared to methicillin sensitive $S$. comorbidities (although this could not be ascertained with aureus (MSSA) infections [70].

Selection bias may be another reason for worse outcomes in PWID compared to non-PWID. PWID were younger; thus, they would be expected to have fewer medical the available data). Consequently, PWID would be expected to have longer survival. However, PWID selected for surgery and included in the referenced series may have had more severe cardiac disease, thus biasing the PWID group towards a

Table 2 Microbiologic and valve characteristics of cases undergoing surgery for infective endocarditis

\begin{tabular}{|c|c|c|c|c|c|c|c|c|}
\hline \multicolumn{9}{|c|}{ Microbiology } \\
\hline & Number of pathogens & Staphylococcus aureus & CONS & Streptococci & Enterococci & GNR or other & Candida & Culture negative \\
\hline PWID & 738 & $317(43)$ & $27(3.7)$ & $123(16.7)$ & $54(7.3)$ & $132(17.9)$ & $42(5.7)$ & $43(5.8)$ \\
\hline non-PWID & 1403 & $346(24.7)$ & $188(13.4)$ & $412(29.4)$ & $170(12.1)$ & $134(9.6)$ & $19(1.4)$ & $134(9.6)$ \\
\hline \multicolumn{9}{|l|}{ Valve data } \\
\hline & Number of valves & Mitral & Aortic & Tricuspid & Pulmonary & Multiple & Embolic events & Prosthetic valve \\
\hline PWID & 922 & $236(25.6)$ & $366(39.7)$ & $309(33.5)$ & $11(1.2)$ & $145(15.7)$ & $190(24.1)$ & $62(7.9)$ \\
\hline non-PWID & 1952 & 719 (36.8) & $1037(53.1)$ & $187(9.6)$ & $9(0.5)$ & $246(12.6)$ & $373(22.5)$ & $501(30.2)$ \\
\hline
\end{tabular}

Abbreviations: CONS Coagulase-negative staphylococci, GNR Gram negative rods; non-PWID People who do not inject drugs, PWID People who inject drugs Numbers denote $n$ (\%)

Percentages were calculated based on the number of pathogens for the microbiologic variables or number of valves reported for the valve-related variables 

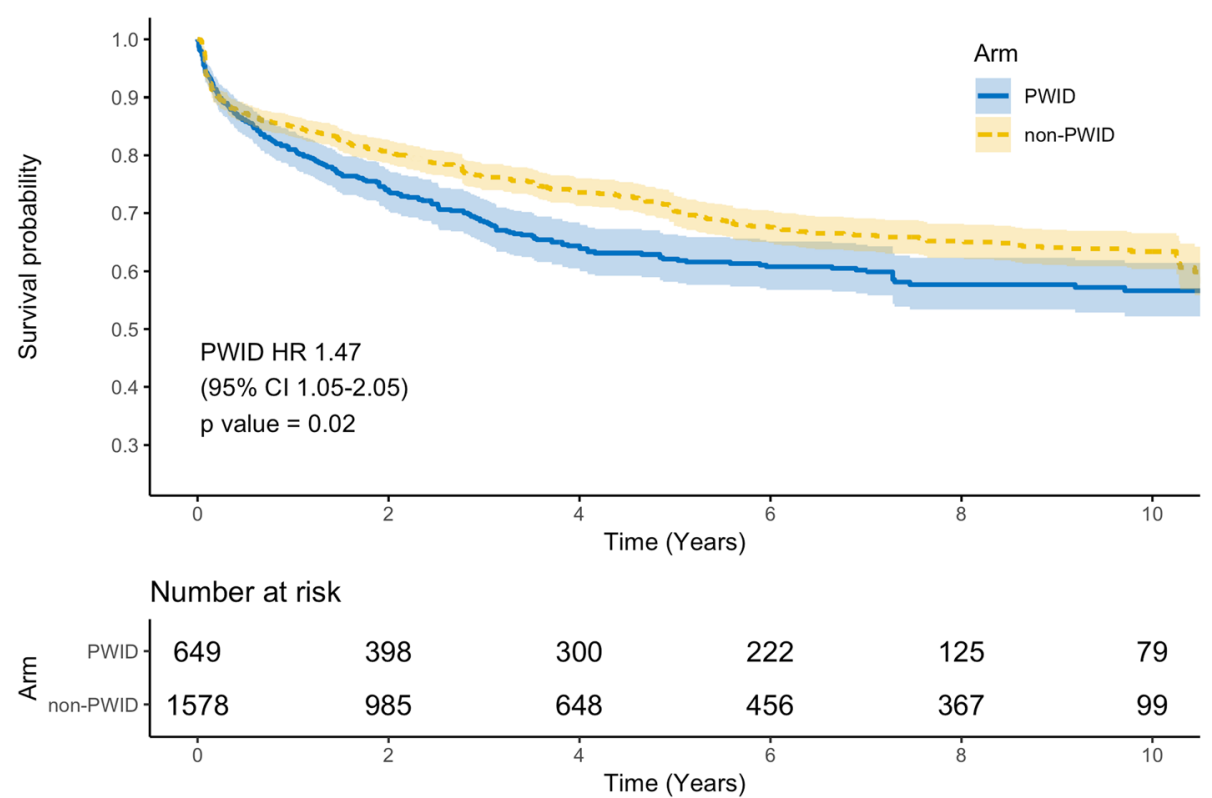

Fig. 2 Survival of PWID and non-PWID after cardiac surgery for infective endocarditis. Abbreviations: non-PWID, people who do not inject drugs; PWID, people who inject drugs

worse survival. A reason for this bias may be stigma towards PWID, resulting in non-surgical management for milder cases, even when evidence suggests superior outcomes with surgery. Additionally, PWIDs' perception of stigmatization from healthcare professionals may delay their engagement with appropriate care [71]. Qualitative studies of PWID support the supposition of the influence of stigma, as stigmatizing interactions with hospital staff were found to delay care of injection-related infections [72]. Delays in care seeking may lead to a delay in appropriate non-surgical treatments (such as early antimicrobial administration for antecedent local or bloodstream infections) that could prevent IE and avoid surgery.

Non-treatment of a PWID's substance use disorder may be an additional reason for our findings. Recurrence of injection drug use after a surgical procedure may have led to increased risk of reoperation in our analysis; however, only a few studies (Asgeirsson, Frater, and Østerdal) reported the proportion of PWID receiving substance use disorder therapy. Despite opioid-type drugs being the most common injection drug in most parts of the world [2] and evidencebased medication-assisted therapies for treating opioid use disorder available since the 1960s [73], few patients actually receive these therapies [7, 74]. In one series of patients with IE, only $10 \%$ received substance use disorder therapy [7], and in another series, over half of cases did not have documentation of a discussion regarding addiction treatment [74]. In the only study to our knowledge to test the effect of medication assisted therapy (MAT) in the setting of endocarditis,
MAT decreased mortality by close to $70 \%$ [75]. More recently, surgical guidelines advocate for a multidisciplinary approach to the management of IE in PWID but a call for MAT was still lacking [18].

This study has many limitations. The gold standard for performing meta-analysis is obtaining IPD. We used a novel algorithm to obtain eIPD and summarize survival curves. This approach has been validated in the past to produce similar survival estimates to the original study. However, this approach limits us in our ability to analyze survival in the context of more granular covariates of interest (e.g., age, infection with $S$. aureus, right vs. left hearted disease, vegetation size, medical comorbidities, HIV and hepatitis C status, provision of addiction therapy). Surgical technique, intraoperative findings (e.g., abscesses, valve rupture), and post-operative complications may be other variables that may differ between PWID and non-PWID to explain differences in survival but were not assessed as part of this study. Due to the wide range in publication dates of the included articles, cardiac surgery techniques and supportive care likely has improved over the time period but this temporal variation was not assessed. As well, patterns of injection drug use have changed over time and geographic space (i.e., increased fentanyl use or increased injection of stimulants) that may lead to different degrees of severity of IE in PWID. The present results may not be reflective of the current epidemiology of injection drug use. As noted above, selection bias may result from the observational and retrospective nature of the included studies. Another limitation was that we only included studies of 


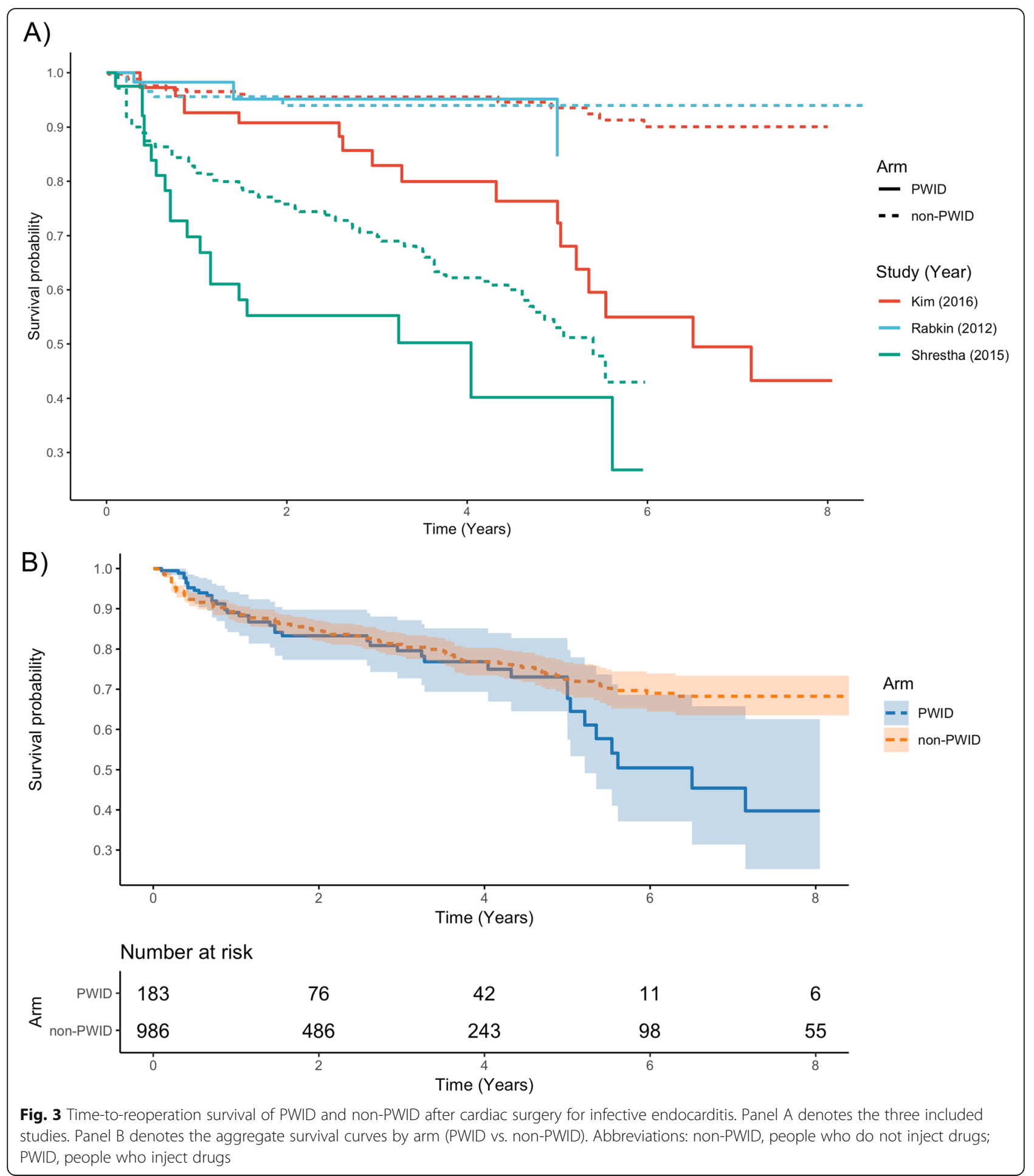

non-PWID that had a head-to-head PWID comparison. Studies from other medical centers that only reported outcomes in non-PWID could alter our survival estimates in this group; however, our main objective was the survival of PWID, thus, we chose to not expand our criteria to include studies of non-PWID only.

\section{Conclusion}

In this systematic review and meta-analysis, PWID had shorter survival than non-PWID after cardiac surgery for IE and a higher risk for reoperation compared to non-PWID. With the expected increases in infectious endocarditis in PWID due to the ongoing drug use 
epidemic in the US and elsewhere, interventions are urgently needed to improve outcomes in this population of young individuals. Interventions that implement substance use disorder treatment and harm-reduction services for patients hospitalized with severe infections and bridge care to the outpatient setting are in need of further study and implementation.

\section{Supplementary information}

Supplementary information accompanies this paper at https://doi.org/10. 1186/s12879-019-4558-2.

Additional file 1: Table S1. Search strings for each database. Table S2. Newcastle-Ottawa scale for qualitative assessment of included studies ( $n=27$ ). Table S3. Microbiologic characteristics by study of patients undergoing surgery for infective endocarditis. Table S4. Valve related characteristics by study of patients undergoing surgery for infective endocarditis. Table S5. Survival at 1-month, 1-, 5-, and 10-years. Fig. S1. Survival by study of patients that underwent cardiac surgery for infective endocarditis stratified by PWID and non-PWID. Fig. S2. Funnel plot of studies comparing mortality in PWID vs. non-PWID after cardiac surgery for infective endocarditis. Fig. S3. Funnel plot of studies comparing reoperation in PWID vs. non-PWID after cardiac surgery for infective endocarditis.

\section{Abbreviations}

Cl: Confidence interval; CONS: Coagulase negative staphylococci; eIPD: Estimated individual patient data; HR: Hazard ratio; IE: Infective endocarditis; IPD: Individual patient data; MAT: Medication assisted therapy; MRSA: Methicillin resistant Staphylococcus aureus; MSSA: Methicillin sensitive Staphylococcus aureus; PWID: People who inject drugs

\section{Acknowledgements}

We thank Patricia Guyot for publication of her algorithm.

\section{Authors' contributions}

D.G.M., R.J.L. and S.S. conceptualized the study. R.E.W. provided statistical guidance. D.G.M. undertook statistical analysis. S.G. and A.G. undertook literature review and database creation. A.A.B. and M.G. provided critical revision of the article. All authors reviewed and approved the final version of the manuscript.

\section{Funding}

D.G.M. was supported by the U.S. National Institute of Mental Health (NIMH) grant number DA-2T32MH080634-11 and National Institute on Drug Abuse grant number 1K08DA048163-01. D.G.M., S.S., R.E.W. and R.J.L. were supported by NIMH grant number P30-MH58107 and the UCLA Center for AIDS Research (CFAR) grant number 5P30AI028697. Funding bodies had no part in the design of the study and collection, analysis, and interpretation of data. The views expressed in this article are those of the authors and do not necessarily reflect the position or policy of the Department of Veterans Affairs or the United States government.

\section{Availability of data and materials}

The datasets used and/or analysed during the current study are available from the corresponding author on reasonable request.

\section{Ethics approval and consent to participate}

Not applicable.

\section{Consent for publication}

Not applicable.

\section{Competing interests}

The authors have no competing interests to declare.

\section{Author details}

'Division of Infectious Diseases, David Geffen School of Medicine at UCLA, 10833 Le Conte Ave (Room 37-121CHS), Los Angeles, CA 90095-1688, USA. ${ }^{2}$ Infectious Diseases, VA Greater Los Angeles Healthcare System, Los Angeles, CA, USA. ${ }^{3}$ Department of Biostatistics, Fielding School of Public Health, UCLA, Los Angeles, CA, USA. ${ }^{4}$ Universidad Autónoma de Baja California, Tijuana, USA. ${ }^{5}$ Medical Imaging Informatics (MII) Group, Department of Radiological Sciences, UCLA, Los Angeles, CA, USA. ${ }^{6}$ Department of Family Medicine, David Geffen School of Medicine at UCLA, Los Angeles, CA, USA. ${ }^{7}$ UCLA Center for Clinical AIDS Research \& Education, David Geffen School of Medicine, Los Angeles, CA, USA.

Received: 22 August 2019 Accepted: 11 October 2019 Published online: 08 November 2019

References

1. Mathers BM, Degenhardt L, Phillips B, Wiessing L, Hickman M, Strathdee SA, et al. Global epidemiology of injecting drug use and HIV among people who inject drugs: a systematic review. Lancet. 2008;372:1733-45.

2. Degenhardt L, Peacock A, Colledge S, Leung J, Grebely J, Vickerman P, et al. Global prevalence of injecting drug use and sociodemographic characteristics and prevalence of HIV, HBV, and HCV in people who inject drugs: a multistage systematic review. Lancet Glob Health. 2017:5:e1192207.

3. Oster AM, Sternberg M, Lansky A, Broz D, Wejnert C, Paz-Bailey G. Population size estimates for men who have sex with men and persons who inject drugs. J Urban Health. 2015;92:733-43.

4. Centers for Disease Control and Prevention (CDC). HIV Surveillance Report, 2016 [Internet]. Centers for Disease Control and Prevention. Atlanta; 2017 [cited 2017 Dec 13]. Available from: https://www.cdc.gov/hiv/pdf/library/ reports/surveillance/cdc-hiv-surveillance-report-2016-vol-28.pdf

5. Zibbell JE, Asher AK, Patel RC, Kupronis B, lqbal K, Ward JW, et al. Increases in acute hepatitis $C$ virus infection related to a growing opioid epidemic and associated injection drug use, United States, 2004 to 2014. Am J Public Health. 2018;108:175-81.

6. Keeshin SW, Feinberg J. Endocarditis as a marker for new epidemics of injection drug use. Am J Med Sci. 2016:352:609-14.

7. Rosenthal ES, Karchmer AW, Theisen-Toupal J, Castillo RA, Rowley CF. Suboptimal addiction interventions for patients hospitalized with injection drug use-associated infective endocarditis. Am J Med. 2016;129:481-5.

8. Abegaz TM, Bhagavathula AS, Gebreyohannes EA, Mekonnen AB, Abebe TB. Short- and long-term outcomes in infective endocarditis patients: a systematic review and meta-analysis. BMC Cardiovasc Disord. 2017;17:291.

9. Ruotsalainen E, Sammalkorpi K, Laine J, Huotari K, Sarna S, Valtonen V, et al. Clinical manifestations and outcome in Staphylococcus aureus endocarditis among injection drug users and nonaddicts: a prospective study of 74 patients. BMC Infect Dis. 2006;6:137.

10. Thalme A, Westling $K$, Julander I. In-hospital and long-term mortality in infective endocarditis in injecting drug users compared to non-drug users: a retrospective study of 192 episodes. Scand J Infect Dis. 2007;39:197-204.

11. Jain V, Yang M-H, Kovacicova-Lezcano G, Juhle LS, Bolger AF, Winston LG. Infective endocarditis in an urban medical center: association of individual drugs with valvular involvement. J Infect. 2008;57:132-8.

12. Alagna L, Park LP, Nicholson BP, Keiger AJ, Strahilevitz J, Morris A, et al. Repeat endocarditis: analysis of risk factors based on the international collaboration on endocarditis - prospective cohort study. Clin Microbiol Infect. 2014;20:566-75.

13. Libertin CR, Camsari UM, Hellinger WC, Schneekloth TD, Rummans TA. The cost of a recalcitrant intravenous drug user with serial cases of endocarditis: need for guidelines to improve the continuum of care. IDCases. 2017;8:3-5.

14. Tookes H, Diaz C, Li H, Khalid R, Doblecki-Lewis S. A cost analysis of hospitalizations for infections related to injection drug use at a county safety-net hospital in Miami. Florida PLoS ONE. 2015:10:e0129360.

15. Schranz AJ, Fleischauer A, Chu VH, Wu L-T, Rosen DL. Trends in drug useassociated infective endocarditis and heart valve surgery, 2007 to 2017. Ann Intern Med. 2018;170:31.

16. Ronan MV, Herzig SJ. Hospitalizations Related To Opioid Abuse/ Dependence And Associated Serious Infections Increased Sharply, 2002-12. Health Aff (Millwood). 2016;35:832-7.

17. Habib G, Lancellotti P, Antunes MJ, Bongiorni MG, Casalta J-P, Del Zotti F, et al. 2015 ESC guidelines for the management of infective endocarditis: the 
task force for the Management of Infective Endocarditis of the European Society of Cardiology (ESC). Endorsed by: European Association for CardioThoracic Surgery (EACTS), the European Association of Nuclear Medicine (EANM). Eur. Heart J. 2015. Pp. 3075-128.

18. AATS Surgical Treatment of Infective Endocarditis Consensus Guidelines Writing Committee Chairs, Pettersson GB, Coselli JS, Writing Committee, Hussain ST, Griffin B, et al. 2016 The American Association for Thoracic Surgery (AATS) consensus guidelines: Surgical treatment of infective endocarditis: Executive summary. J. Thorac. Cardiovasc. Surg. 2017;153:1241-1258.e29.

19. Baddour LM, Wilson WR, Bayer AS, Fowler VG, Tleyjeh IM, Rybak MJ, et al. Infective endocarditis in adults: diagnosis, antimicrobial therapy, and Management of Complications: a scientific statement for healthcare professionals from the American Heart Association. Circulation. 2015;132:1435-86.

20. Aksoy O, Sexton DJ, Wang A, Pappas PA, Kourany W, Chu V, et al. Early surgery in patients with infective endocarditis: a propensity score analysis. Clin Infect Dis. 2007;44:364-72.

21. Lalani T, Cabell CH, Benjamin DK, Lasca O, Naber C, Fowler VG, et al. Analysis of the impact of early surgery on in-hospital mortality of native valve endocarditis: use of propensity score and instrumental variable methods to adjust for treatment-selection bias. Circulation. 2010;121:1005-13.

22. Mirabel M, Sonneville R, Hajage D, Novy E, Tubach F, Vignon P, et al. Long-term outcomes and cardiac surgery in critically ill patients with infective endocarditis. Eur Heart J. 2014;35:1195-204.

23. DiMaio JM, Salerno TA, Bernstein R, Araujo K, Ricci M, Sade RM. Ethical obligation of surgeons to noncompliant patients: can a surgeon refuse to operate on an intravenous drug-abusing patient with recurrent aortic valve prosthesis infection? Ann Thorac Surg. 2009;88:1-8.

24. Bromage DI, McLauchlan DJ, Nightingale AK. Do cardiologists and cardiac surgeons need ethics? Achieving happiness for a drug user with endocarditis. Heart. 2009;95:885-7.

25. Miljeteig I, Skrede S, Langørgen J, Haaverstad R, Jøsendal O, Sjursen H, et al. Should patients who use illicit drugs be offered a second heart-valve replacement? Tidsskr Nor Laegeforen. 2013;133:977-80.

26. Hull SC, Jadbabaie F. When is enough enough? The dilemma of valve replacement in a recidivist intravenous drug user. Ann Thorac Surg. 2014;97:1486-7.

27. Vlahakes GJ. "Consensus guidelines for the surgical treatment of infective endocarditis": the surgeon must lead the team. J Thorac Cardiovasc Surg. 2017;153:1259-60.

28. Wurcel AG, Yu S, Pacheco M, Warner K. Contracts with people who inject drugs following valve surgery: unrealistic and misguided expectations. J Thorac Cardiovasc Surg. 2017;154:2002.

29. Mishra R. Does blame trump benefit in treatment decisions? Nonadherence and cardiac surgery. Am J Bioeth. 2018;18:81-3.

30. Yanagawa B, Bahji A, Lamba W, Tan DH, Cheema A, Syed I, et al. Endocarditis in the setting of IDU: multidisciplinary management. Curr Opin Cardiol. 2018;33:140-7.

31. Hall R, Shaughnessy M, Boll G, Warner K, Boucher HW, Bannuru RR, et al. Drug-use and post-operative mortality following valve surgery for infective endocarditis: a systematic review and Meta-analysis. Clin Infect Dis. 2018; 169:463.

32. Goodman-Meza D, Gamboa S, Gallegos A. A systematic review and metaanalysis of outcomes in valve surgery for infective endocarditis in people who inject drugs [Internet]. PROSPERO. 2018 [cited 2018 May 23]. Available from: https://www.crd.york.ac.uk/PROSPERO/display_record.php? RecordID=93727.

33. Stewart LA, Clarke M, Rovers M, Riley RD, Simmonds M, Stewart G, et al. Preferred reporting items for systematic review and Meta-analyses of individual participant data: the PRISMA-IPD statement. JAMA. 2015;313:1657-65.

34. Guyot P, Ades AE, Ouwens MJNM, Welton NJ. Enhanced secondary analysis of survival data: reconstructing the data from published Kaplan-Meier survival curves. BMC Med Res Methodol. 2012;12:9.

35. Wan $X$, Peng L, Li Y. A review and comparison of methods for recreating individual patient data from published Kaplan-Meier survival curves for economic evaluations: a simulation study. PLoS One. 2015;10:e0121353.

36. Kassambara A, Kosinski M, Biecek P, Fabian S. Drawing Survival Curves using "ggplot2" [R package survminer version 0.4.2]. Comprehensive R Archive Network (CRAN); 2018.

37. Therneau TM. Survival Analysis [R package survival version 2.42-3]. Comprehensive R Archive Network (CRAN); 2015. Available from: https:// CRAN.R-project.org/package=survival

38. Schwarzer G, Carpenter JR, Rücker G. Meta-analysis with R. Cham: Springer International Publishing; 2015.
39. Arbulu A. Trivalvular/bivalvular heart: a philosophical, scientific and therapeutic concept. J Heart Valve Dis. 2000;9:353-8.

40. Asgeirsson $H$, Thalme A, Weiland O. Low mortality but increasing incidence of Staphylococcus aureus endocarditis in people who inject drugs: experience from a Swedish referral hospital. Medicine. 2016;95: e5617.

41. Baraki H, Saito S, Ahmad Al A, Fleischer B, Schmitto J, Haverich A, et al. Surgical treatment for isolated tricuspid valve endocarditis- long-term follow-up at a single institution. Circ J. 2013;77:2032-7.

42. Boyd AD, Spencer FC, Isom OW, Cunningham JN, Reed GE, Acinapura AJ, et al. Infective endocarditis. An analysis of 54 surgically treated patients. J Thorac Cardiovasc Surg. 1977;73:23-30.

43. Carozza A, De Santo LS, Romano G, Corte Della A, Ursomando F, Scardone $M$, et al. Infective endocarditis in intravenous drug abusers: patterns of presentation and long-term outcomes of surgical treatment. J. Heart Valve Dis. 2006;15:125-31.

44. Carrel T, Schaffner A, Vogt P, Laske A, Niederhäuser U, Schneider J, et al. Endocarditis in intravenous drug addicts and HIV infected patients: possibilities and limitations of surgical treatment. J. Heart Valve Dis. 1993;2:140-7.

45. Dawood MY, Cheema FH, Ghoreishi M, Foster NW, Villanueva RM, Salenger $\mathrm{R}$, et al. Contemporary outcomes of operations for tricuspid valve infective endocarditis. Ann Thorac Surg. 2015;99:539-46.

46. Frater RW, Sisto D, Condit D. Cardiac surgery in human immunodeficiency virus (HIV) carriers. Eur J Cardiothorac Surg. 1989;3:146-51.

47. Frater RW. Surgical management of endocarditis in drug addicts and longterm results. J Card Surg. 1990;5:63-7.

48. Hubbell G, Cheitlin MD, Rapaport E. Presentation, management, and follow-up evaluation of infective endocarditis in drug addicts. Am Heart J. 1981;102:85-94

49. Kaiser SP, Melby SJ, Zierer A, Schuessler RB, Moon MR, Moazami N, et al. Long-term outcomes in valve replacement surgery for infective endocarditis. Ann Thorac Surg. 2007;83:30-5.

50. Kim JB, Ejiofor JI, Yammine M, Ando M, Camuso JM, Youngster I, et al. Surgical outcomes of infective endocarditis among intravenous drug users. J. Thorac. Cardiovasc. Surg. 2016;152:832-841.e1.

51. Levitsky S, Mammana RB, Silverman NA, Weber F, Hiro S, Wright RN. Acute endocarditis in drug addicts: surgical treatment for gram-negative sepsis. Circulation. 1982;66:1135-8.

52. Mammana RB, Levitsky S, Sernaque D, Beckman CB, Silverman NA. Valve replacement for left-sided endocarditis in drug addicts. Ann Thorac Surg. 1983;35:436-41.

53. Martín-Dávila P, Navas E, Fortún J, Moya JL, Cobo J, Pintado V, et al. Analysis of mortality and risk factors associated with native valve endocarditis in drug users: the importance of vegetation size. Am Heart J. 2005;150:1099-106.

54. Marks DJB, Hyams C, Koo CY, Pavlou M, Robbins J, Koo CS, et al. Clinical features, microbiology and surgical outcomes of infective endocarditis: a 13-year study from a UK tertiary cardiothoracic referral Centre. QJM. 2015;108:219-29.

55. Mathew J, Abreo G, Namburi K, Narra L, Franklin C. Results of surgical treatment for infective endocarditis in intravenous drug users. Chest. 1995;108:73-7.

56. Mestres C. Long-term results after cardiac surgery in patients infected with the human immunodeficiency virus type-1 (HIV-1). Eur J Cardiothorac Surg. 2003:23:1007-16.

57. Hiratzka LF, Nelson RJ, Oliver CB, Jengo JA. Operative experience with infective endocarditis. Drug users compared with non-drug users. J Thorac Cardiovasc Surg. 1979;77:355-61.

58. Nelson RJ, Harley DP, French WJ, Bayer AS. Favorable ten-year experience with valve procedures for active infective endocarditis. J Thorac Cardiovasc Surg. 1984;87:493-502.

59. Østerdal OB, Salminen P-R, Jordal S, Sjursen H, Wendelbo Ø, Haaverstad R. Cardiac surgery for infective endocarditis in patients with intravenous drug use. Interact Cardiovasc Thorac Surg. 2016;22:633-40.

60. Pfannmueller B, Kahmann M, Davierwala P, Misfeld M, Bakhtiary F, Binner C, et al. Tricuspid valve surgery in patients with isolated tricuspid valve endocarditis: analysis of perioperative parameters and long-term outcomes. Thorac Cardiovasc Surg. 2017;65:626-33.

61. Rabkin DG, Mokadam NA, Miller DW, Goetz RR, Verrier ED, Aldea GS Long-term outcome for the surgical treatment of infective endocarditis with a focus on intravenous drug users. Ann Thorac Surg. 2012;93:51-7.

62. Shetty N, Nagpal D, Koivu S, Mrkobrada M. Surgical and medical Management of Isolated Tricuspid Valve Infective Endocarditis in intravenous drug users. J Card Surg. 2016;31:83-8. 
63. Shrestha NK, Jue J, Hussain ST, Jerry JM, Pettersson GB, Menon V, et al. Injection drug use and outcomes after surgical intervention for infective endocarditis. Ann Thorac Surg. 2015;100:875-82.

64. Silverman NA, Levitsky S, Mammana R. Acute endocarditis in drug addicts: surgical treatment for multiple valve infection. J Am Coll Cardiol. 1984;4:680-4.

65. Weymann A, Borst T, Popov A-F, Sabashnikov A, Bowles C, Schmack B, et al. Surgical treatment of infective endocarditis in active intravenous drug users: a justified procedure? J Cardiothorac Surg. 2014;9:58.

66. Ying I, Chan V, Rubens F, Tyndall M. Long Term Outcomes of Valve Surgery in the Treatment of Infective Endocarditis within the Injection Drug Use Population [Internet]. IDWeek. San Francisco, USA; 2013 [cited 2018 Sep 11]. Available from: https:/idsa.confex.com/idsa/2013/webprogram/Paper39397.html

67. Gordon RJ, Lowy FD. Bacterial infections in drug users. N Engl J Med. 2005; 353:1945-54.

68. Asgeirsson $\mathrm{H}$, Thalme A, Weiland O. Staphylococcus aureus bacteraemia and endocarditis - epidemiology and outcome: a review. Infect Dis. 2018;50: 175-92.

69. Jackson KA, Bohm MK, Brooks JT, Asher A, Nadle J, Bamberg WM, et al. Invasive methicillin-resistant staphylococcus aureusInfections among persons who inject drugs - six sites, 2005-2016. MMWR Morb Mortal Wkly Rep. 2018;67:625-8.

70. Goto M, Schweizer ML, Vaughan-Sarrazin MS, Perencevich EN, Livorsi DJ, Diekema DJ, et al. Association of Evidence-Based Care Processes with Mortality in Staphylococcus aureus bacteremia at veterans health administration hospitals, 2003-2014. JAMA Intern Med. 2017;177:1489-97.

71. Paquette CE, Syvertsen JL, Pollini RA. Stigma at every turn: health services experiences among people who inject drugs. Int J Drug Policy. 2018;57:104-10.

72. Fukuchi T, Iwata K. Ohji G. Failure of early diagnosis of infective endocarditis in Japan--a retrospective descriptive analysis. Medicine. 2014;93:e237.

73. Dole VP, Nyswander M. A medical treatment for diacetylmorphine (heroin) addiction: a clinical trial with methadone hydrochloride. JAMA. 1965;193; 646-50.

74. Gray ME, Rogawski McQuade ET, Scheld WM, Dillingham RA. Rising rates of injection drug use associated infective endocarditis in Virginia with missed opportunities for addiction treatment referral: a retrospective cohort study. BMC Infect Dis. 2018;18:532.

75. Rodger L, Glockler-Lauf SD, Shojaei E, Sherazi A, Hallam B, Koivu S, et al. Clinical characteristics and factors associated with mortality in first-episode infective endocarditis among persons who inject drugs. JAMA Netw Open. 2018;1:e185220.

\section{Publisher's Note}

Springer Nature remains neutral with regard to jurisdictional claims in published maps and institutional affiliations.

Ready to submit your research? Choose BMC and benefit from:

- fast, convenient online submission

- thorough peer review by experienced researchers in your field

- rapid publication on acceptance

- support for research data, including large and complex data types

- gold Open Access which fosters wider collaboration and increased citations

- maximum visibility for your research: over $100 \mathrm{M}$ website views per year

At BMC, research is always in progress.

Learn more biomedcentral.com/submissions 